\title{
1 Regional Association of Disability and SARS-CoV-2 Infection in 369 Counties of the United States
}

2 Running Title: SARS-CoV-2 Infection among non-institutionalized disabled population

3 Authors: Oluwaseyi Olulana ${ }^{a}$, Vida Abedi ${ }^{b, d}$, Venkatesh Avula ${ }^{b}$, Durgesh Chaudhary ${ }^{c}$, Ayesha Khan $^{c}$, Shima

4 Shahjoueic, Jiang Li ${ }^{b}$, Ramin Zand ${ }^{c}$

$5 \quad{ }^{a}$ Geisinger Commonwealth School of Medicine, Scranton PA, United States

6 b Department of Molecular and Functional Genomics, Weis Center for Research, Geisinger Health System,

7 Danville PA, United States.

$8{ }^{\mathrm{c}}$ Geisinger Neuroscience Institute, Geisinger Health System, Danville PA, United States.

$9 \quad{ }^{\mathrm{d}}$ Biocomplexity Institute, Virginia Tech, Blacksburg, VA United States.

11 Word Count: 2076

12 Tables:3 (5 tables in supplement)

13 Figures: 2 (2 figures in supplement)

15 Author's contribution: VA and RZ designed the study. OO and VeA extracted and prepared the data for 16 analysis. AK and DC performed data validation. JL, RZ, OO, and VA performed the analysis. JL, RZ, OO, SS 17 and VA contributed to the interpretation of the results. VA and OO wrote the initial draft. All authors provided 18 critical feedback and contributed to different sections of the manuscript. All authors reviewed and approved the 19 final version of the manuscript.

21 Source of Funding: RZ and VA have funding support from the Geisinger Health Plan Quality Fund as well as

22 the National Institute of Health R56HL116832 (sub-award) during the study period. The funders had no role in 23 study design, data collection, and interpretation, or the decision to submit the work for publication.

24 Conflict of Interest: The authors declare no competing interests.

25 Corresponding Author:

26 Ramin Zand, MD, MPH

27 Associate Professor of Neurology and Medicine 
medRxiv preprint doi: https://doi.org/10.1101/2020.06.24.20139212; this version posted June 26, 2020. The copyright holder for this preprint (which was not certified by peer review) is the author/funder, who has granted medRxiv a license to display the preprint in perpetuity.

It is made available under a CC-BY-ND 4.0 International license .

28

Director, Stroke Program, Geisinger Northeast Region

29

100 N Academy Ave, Danville PA 17822

30 Ph: 570-808-7330 | Fax: 570-808-3209 | rzand@geisinger.edu; ramin.zand@gmail.com

31

32 
medRxiv preprint doi: https://doi.org/10.1101/2020.06.24.20139212; this version posted June 26, 2020. The copyright holder for this preprint (which was not certified by peer review) is the author/funder, who has granted medRxiv a license to display the preprint in perpetuity.

It is made available under a CC-BY-ND 4.0 International license .

\section{Abstract}

Background: There have been outbreaks of SARS-CoV-2 in long term care facilities and recent reports of disproportionate death rates among the vulnerable population. The goal of this study was to better understand the impact of SARS-CoV-2 infection on the non-institutionalized disabled population in the United States using data from the most affected states as of April 9th, 2020.

Methods: This was an ecological study of county-level factors associated with the infection and mortality rate of SARS-CoV-2 in the non-institutionalized disabled population. We analyzed data from 369 counties from the most affected states (Michigan, New York, New Jersey, Pennsylvania, California, Louisiana, Massachusetts) in

41 the United States using data available by April 9th, 2020. The variables include changes in mobility reported by

42 Google, race/ethnicity, median income, education level, health insurance, and disability information from the

43 United States Census Bureau. Bivariate regression analysis adjusted for state and median income was used to

44 analyze the association between death rate and infection rate.

45 Results: The independent sample t-test of two groups (group 1: Death rate $\geq 3.4 \%$ [median] and group 2:

46 Death rate $<3.4 \%$ ) indicates that counties with a higher total population, a lower percentage of Black males

47 and females, higher median income, higher education, and lower percentage of disabled population have a

48 lower rate $(<3.4 \%)$ of SARS-CoV-2 related mortality (all $p$-values $<4.3 \mathrm{E}-02)$. The results of the bivariate

49 regression when controlled for median income and state show counties with a higher White disabled

50 population (est: $0.19,95 \%$ CI: $0.01-0.37$; p-value:3.7E-02), and higher population with independent living

51 difficulty (est: 0.15,95\% CI: -0.01-0.30; p-value: 6.0E-02) have a higher rate of SARS-CoV-2 related

52 mortality. Also, the regression analysis indicates that counties with higher White disabled population (est: -

$530.22,95 \%$ CI: -0.43-(-0.02); p-value: 3.3E-02), higher population with hearing disability (est: $-0.26,95 \%$ CI: -

54 0.42- (-0.11); $p$-value:1.2E-03), and higher population with disability in the 18-34 years age group (est: -0.25 ,

55 95\% CI: -0.41-(-0.09); p-value:2.4E-03) show a lower rate of SARS-CoV-2 infection.

56 Conclusion: Our results indicate that while counties with a higher percentage of non-institutionalized disabled

57 population, especially White disabled population, show a lower infection rate, they have a higher rate of

58 SARS-CoV-2 related mortality. 
medRxiv preprint doi: https://doi.org/10.1101/2020.06.24.20139212; this version posted June 26, 2020. The copyright holder for this preprint (which was not certified by peer review) is the author/funder, who has granted medRxiv a license to display the preprint in perpetuity.

It is made available under a CC-BY-ND 4.0 International license .

59 Keywords: Disability disparities, Healthcare disparities, Non-institutionalized disabled population, Racial

60 disparity, Health disparity, Socioeconomic factors, COVID19, United States, Population-based analysis,

61 Ecological study.

62

63 
medRxiv preprint doi: https://doi.org/10.1101/2020.06.24.20139212; this version posted June 26, 2020. The copyright holder for this preprint (which was not certified by peer review) is the author/funder, who has granted medRxiv a license to display the preprint in perpetuity.

It is made available under a CC-BY-ND 4.0 International license.

\section{INTRODUCTION}

65 The continuous spread of severe acute respiratory syndrome coronavirus 2 (SARS-CoV-2) has highlighted

66 disparities in the infection and mortality rates of this disease. ${ }^{1}$ The outbreak in a nursing home in Kirkland,

67 Washington ${ }^{2}$ was the first to report death due to SARS-CoV-2 in the United States (U.S). As of May 26, 2020,

68 there are over 5.6 million confirmed cases worldwide, with over 1.6 million SARS-CoV-2 cases and 99,123

69 deaths in the U.S. ${ }^{3}$ SARS-CoV-2 initially attacks the respiratory system $;{ }^{4}$ with groups most susceptible to the

70 infection and death being people aged 65 years and older, as well as people with certain chronic conditions and

71 comorbidities. People living in nursing homes or long-term care facilities are more prone to the infection. 5,6

72 Recently, states are releasing data on the number of deaths from long term care facilities ${ }^{7}$ with the most recent

73 report stating that more than 10,000 patients and staff in long term facilities have died, ${ }^{8}$ accentuating the

74 disparities in the outcomes of the disabled population in the U.S. The populations with higher disability are

75 affected by the lower quality of care and increased comorbidities ${ }^{9,10}$ even before the evidence of disparities in

76 the SARS-CoV-2 outcomes was reported. However, there have been few reports concerning the non-

77 institutionalized disabled population and the risk of mortality and infection by SARS-CoV-2. ${ }^{11}$ To provide

78 targeted preventive strategies, adequate resources for the disabled population and their care providers, an

79 examination into the infection among the non-institutionalized disabled population is a necessary first step.

80 The goal of this ecological study was to determine the association between county-level non-institutionalized

81 disability rates, socioeconomic factors, and SARS-CoV-2 infection and death; we hypothesized that non-

82 institutionalized disability rates in counties are associated with the rate of SARS-CoV-2 infection and death.

\section{METHODOLOGY:}

84 We conducted an ecological analysis of demographic, mobility, socioeconomic, and disability information, in

85 the context of SARS-CoV-2 data in 369 counties in California, Michigan, New York, New Jersey, Louisiana,

86 Pennsylvania, and Massachusetts with the initial highest SARS-CoV-2 infection and death rates as of April $9^{\text {th }}$,

872020.

88 Data source: 
medRxiv preprint doi: https://doi.org/10.1101/2020.06.24.20139212; this version posted June 26, 2020. The copyright holder for this preprint (which was not certified by peer review) is the author/funder, who has granted medRxiv a license to display the preprint in perpetuity.

It is made available under a CC-BY-ND 4.0 International license .

89 Data sources in this study include publicly available data from United States Census Bureau data estimated for

902018 for demographic data per county ${ }^{12,13}$ USAFacts for SARS-CoV-2 cases estimated for the year $2020,{ }^{14}$

91 and mobility data provided by Google, as of April $5^{\text {th }}, 2020 . .^{15}$

92 According to Social Security, individuals who cannot engage in substantial productive activity due to

93 medically diagnosable physical or mental impairment which is expected to lead to death or last for over twelve

94 months are legally defined as disabled. ${ }^{16}$ The non-institutionalized disabled population was defined as

95 individuals not in a nursing home, prisons, or confined to any other facilities.

96 The data elements in this study included: 1) mobility data for each county, reported by Google on April $5^{\text {th }}$,

972020 , that captured percent increase or decrease in mobility (grocery mobility, retail mobility, transit mobility,

98 park mobility, work mobility, and resident mobility); 2) county-level data for total disabled population by

99 race/ethnicity, age, gender, and type of disability along with data on total population, median income,

100 education level, and access to health insurance, all data elements extracted from the United States Census

101 Bureau. Table 1 summarizes a detailed description of the data elements used in this study. The outcome

102 variables, infection and mortality rates were reported by USAFacts. ${ }^{14}$ County-level SARS-CoV-2 infection and

103 mortality cases were extracted from the state's health departments through data from hospitals, nursing homes,

104 and other health organizations as reported on April 9 $9^{\text {th }}, 2020$.

105 Outcome Measures

106 The outcome measure is the county-level SARS-CoV-2 infection and mortality rates for the non-

107 institutionalized disabled population. The infection and mortality rates were based on CDC guidelines ${ }^{17}$

108 (numerator: confirmed cases or death; denominator: total population per county). The mean of the infection

109 rates or death rates were used for the comparative analysis as described below.

110 Statistical Analysis

111 The data elements in this study were described using their mean \pm standard deviation unless otherwise stated.

112 An independent sample t-test was used to determine statistical significance in SARS-CoV-2 infection and

113 death rates in comparison to the mobility, race/ethnicity, disability, median income, insured population, and

114 total populations in the 369 counties. Bivariate regression adjusted for the state, and median income, \pm total 
medRxiv preprint doi: https://doi.org/10.1101/2020.06.24.20139212; this version posted June 26, 2020. The copyright holder for this preprint (which was not certified by peer review) is the author/funder, who has granted medRxiv a license to display the preprint in perpetuity.

It is made available under a CC-BY-ND 4.0 International license .

115 population was used to analyze the association between death rate or infection rate. Statistical analyses were

116 performed using the IBM SPSS Statistics $26^{18}$ and R version 3.6.2. ${ }^{19}$

117 RESULTS

118 SARS-CoV-2 infection and mortality in the seven states during the first peak of infection in the U.S.

119 The county-level data from 369 counties from Michigan, New York, New Jersey, Pennsylvania,

120 Massachusetts, California, and Louisiana (mean population: 276,905.5 $\pm 683,001.8$ ) with the highest number

121 of SARS-CoV-2 infection (as of April 9 $9^{\text {th }}, 2020$ ) in the U.S. were included in this study.

122 The mean and 95\% confidence interval (CI) for race/ethnicity, disability age group, and disability by gender

123 are available in Table S1. The mean rate of disability in the U.S. population for the states used in the study was

$124 \quad 15.0 \% \pm 3.7 \%$; this rate for males was $13.1 \% \pm 3.1 \%$ and for the female population was at $13.4 \% \pm 2.8 \%$.

125 Disability in the race/ethnic groups ranged differently with the average of disability in the Black population

$126(15.4 \% \pm 6.1 \%)$ as the highest; disability in the Asian population $(7.9 \% \pm 3.9 \%)$ was the lowest; disability rate

127 in the white population was at $14.0 \% \pm 2.9 \%$. The age of the disabled population varied with the majority being

12875 years or older $(47.1 \% \pm 6.0 \%)$ and lowest in disability age group 5 to 17 years at $6.3 \% \pm 2.5 \%$. Lastly, the

129 disability types also varied within the population, ambulatory disability represents the highest type of disability

130 at $7.0 \% \pm 1.7 \%$ on average, while individuals with self-care difficulty were on average at $2.7 \% \pm 0.7 \%$. The

131 hearing difficulty was at $3.7 \% \pm 1.1 \%$, while vision difficulty was at $2.2 \% \pm 0.8 \%$, cognitive difficulty at

$1325.4 \% \pm 1.4 \%$, and independent living disability was at $6.1 \% \pm 1.4 \%$. The mean infection rate was

$1331593.0 \pm 2768.9$ per million with a median of 555.5, [IQR: 245.2-1486.6] while the mean mortality rate was

$1343.8 \% \pm 2.2 \%$ and median of $3.4 \%$ [IQR: $2.2 \%-5.4 \%]$.

135 The independent sample t-test of the two groups (group 1: Death rate $\geq 3.4 \%$ [median] and group 2: Death rate

$136<3.4 \%$; Table 2) indicated that counties with a higher total population, reduction in retail mobility, a lower

137 percentage of Black males and females, higher median income, higher education, lower percentage of disabled

138 population, and a lower percentage of disabled in the age group of 35 to 64 years had a lower rate $(<3.4 \%)$ of

139 SARS-CoV-2 related mortality (all $p$-values $<4.3 \mathrm{E}-02$ ). Additionally, a higher rate of SARS-CoV-2 infection

140 was observed in counties with a higher population, a higher percentage of Black males and females, a higher 
medRxiv preprint doi: https://doi.org/10.1101/2020.06.24.20139212; this version posted June 26, 2020. The copyright holder for this preprint (which was not certified by peer review) is the author/funder, who has granted medRxiv a license to display the preprint in perpetuity.

It is made available under a CC-BY-ND 4.0 International license.

141 median income, higher percentage of bachelor or graduate degree, a lower percentage of the disabled

142 population, specifically a lower percentage of disabled individuals with hearing difficulty, and a lower

143 percentage of disabled in the age group of 35 to 64 and 65 to 74 years (Table 3 , all $p$-values $<2.3 \mathrm{E}-02$ ).

144 Regression analysis showed a higher white disabled population, and independent living difficulty had a

145 higher rate of SARS-CoV-2 related mortality.

146 The results of the bivariate regression analysis (Figure 1, Table S2) estimate the effect size of disability sub-

147 groups associated with SARS-CoV-2 related mortality when controlled for the median income and state.

148 Counties with a higher percentage of White disabled population (est: 0.19, 95\% CI: 0.01-0.37; p-value:3.7E-

149 02), higher population with independent living difficulty (est: 0.15, 95\% CI: -0.01-0.30; p-value: 6.0E-02), and

150 higher disability in the age group 18-34 years (est:0.17, 95\% CI: 0.02-0.31; $p$-value:2.4E-02) showed a higher

151 rate of SARS-CoV-2 related mortality. The same trend is observed when controlling for the total population,

152 median income and state in the bivariate regression model (Figure S1, Table S3).

153 Regression analysis indicates no significant difference in SARS-CoV-2 related Infection rates among

154 counties with different disability rates.

155 The bivariate regression analysis was controlled for median income and state (Figure 2, Table S4), we

156 observed that counties with higher percentage of White disabled population (est: $-0.22,95 \%$ CI: -0.43-(-0.02);

$157 p$-value: 3.3E-02), higher percentage of people with hearing disability (est: -0.26, 95\% CI: -0.42-(-0.11); $p$ -

158 value:1.2E-03), and higher percentage of people with disability in the 18-34 years age group (est: $-0.25,95 \%$

159 CI: -0.41-(-0.09); $p$-value:2.4E-03) showed a lower rate of SARS-CoV-2 infection. The bivariate regression

160 analysis of the SARS-CoV-2 Infection rate when controlled for the total population, median income, and state

161 showed no observed statistical significance in disability or any of the disability types (Figure S2, Table S5).

\section{DISCUSSION}

163 Our results indicate that counties with a higher percentage of non-institutionalized White disabled and a higher

164 rate of independent living difficulty show a higher rate of SARS-CoV-2 related mortality. These results are

165 plausible with the knowledge that the disabled population has a higher rate of obesity, ${ }^{20-23}$ lack of physical

166 activity, ${ }^{20,22,23}$ diabetes, ${ }^{9,23,24}$ higher rates of cardiovascular diseases ${ }^{9,23,24}$ that limits their body's ability to fight

167 the SARS-CoV-2 infection, which can ultimately lead to a poor outcome. ${ }^{9,10}$ Another reason for the high 
medRxiv preprint doi: https://doi.org/10.1101/2020.06.24.20139212; this version posted June 26, 2020. The copyright holder for this preprint (which was not certified by peer review) is the author/funder, who has granted medRxiv a license to display the preprint in perpetuity.

It is made available under a CC-BY-ND 4.0 International license.

mortality rates could be due to the independent living difficulty that may have been compounded by the pandemic such as transportation limitations, grocery access, reduced opportunity for daily care, and essential services. ${ }^{25}$ Additionally, in anticipation of a supply crisis, many health departments around the U.S. considered

171 options on how to triage patients who should be given the most aggressive life-saving therapies in the event of

172 a supply shortage. ${ }^{26}$ In Washington state, a plan was put forward to withhold advanced care for patients with

173 heart failure, chronic lung and liver disease among other organ dysfunctions; diseases that are common co-

174 morbidities with the adult disabled population..$^{26-28}$ Although this action was not officially taken in the U.S,

175 there is a history of systematic discrimination in policies and treatment of disabled patients and lack of

176 adequate preparedness for disabled patients during a pandemic..$^{23}$

177 The center for disease control and prevention (CDC) cautioned that difficulty to understand information,

178 limited mobility, and inability to communicate symptoms/illness may put the disabled patient population at risk. ${ }^{29}$ Alternatively, our results when adjusted for state and median income show counties with higher White disabled population and higher hearing disabled population have a lower rate of SARS-CoV-2 infection. There

181 is a possibility that people with a hearing disability are overcompensated with visual information,$^{30}$ which

182 could potentially increase their attentiveness to the visual information concerning the spread of SARS-CoV-2

183 and their adherence to the enforced state-wide recommendations for the pandemic. Nonetheless, understanding

184 how this sub-population is potentially better-protected needs further investigation.

185 Additionally, there was no significant difference in any of the disability groups when the analysis was

186 controlled for population size, median income, and state. Although our bivariate regression analysis results on

187 SARS-CoV-2 infection rate show there is no significance among states with different disability rates, this

188 finding is not consistent with reports that the disabled population is at a higher risk of infection, ${ }^{27,31}$ we

189 emphasize that the studied population was non-institutionalized disabled, so the trends may be different from

190 studies that include both the institutionalized and non-institutionalized disabled population. ${ }^{31}$ The influenza

191 pandemics showed that disabled patients are at an increased risk of infection, but also less likely to have access

192 to vaccinations or be educated on their medical needs. ${ }^{31}$ The disabled population are at an increased risk of

193 exposure, complication, and death due to their reliance on health services that may be on hold during

194 pandemics, and if those services are available, they run the risk of exposure to the virus. ${ }^{31}$ 
medRxiv preprint doi: https://doi.org/10.1101/2020.06.24.20139212; this version posted June 26, 2020. The copyright holder for this preprint (which was not certified by peer review) is the author/funder, who has granted medRxiv a license to display the preprint in perpetuity.

It is made available under a CC-BY-ND 4.0 International license .

195 This study provides some insight into how the counties with higher non-institutionalized disabled population

196 may be affected by SARS-CoV-2 in the most affected states during the first wave of infection in the United

197 States. SARS-CoV-2 is a call to pay more attention to this sub-population of non-institutionalized disabled

198 civilians that are $12.7 \%^{32}$ of the total U.S population especially since the population is expected to see a $20 \%$

199 increase in adults over 65 years or older within the next decade,,$^{33}$ this age group is currently $40 \%{ }^{34}$ of the

200 disabled population. It is imperative that policies and programs are being put in place to avoid a public health

201 crisis in the future for this group..$^{31}$

202 Several limitations were observed in this study; the data used in this study was based on the county level. The

203 data on the infection rate is likely an underestimate of the true cases, especially for the healthier population. In

204 the future, we will continue to monitor and study the impact of the infection on this vulnerable population.

205 In conclusion, our results indicate that while counties with a higher percentage of the non-institutionalized

206 disabled population, especially White disabled population, show a lower infection rate, they have a higher rate

207 of SARS-CoV-2 related mortality. 
medRxiv preprint doi: https://doi.org/10.1101/2020.06.24.20139212; this version posted June 26, 2020. The copyright holder for this preprint (which was not certified by peer review) is the author/funder, who has granted medRxiv a license to display the preprint in perpetuity.

It is made available under a CC-BY-ND 4.0 International license .

\section{References}

210 1. Vida Abedi, Oluwaseyi Olulana, Venkatesh Avula, Durgesh Chaudhary, Ayesha Khan, Shima Shahjouei,

211 Jiang Li, R. Z. Racial, Economic and Health Inequality and COVID-19 Infection in the United States.

212 2. Boodman, Eric and Branswell, H. First Covid-19 outbreak in a U.S. Nursing Home Raises Concerns. (2020). Available at: https://www.statnews.com/2020/02/29/new-covid-19-death-raises-concerns-aboutvirus-spread-in-nursing-homes/. (Accessed: 29th April 2020)

215 3. JHU. COVID-19 Dashboard by the Center for Systems Science and Engineering. Available at:

216 https://coronavirus.jhu.edu/map.html. (Accessed: 29th April 2020)

217 4. Rothan, H. A. \& Byrareddy, S. N. The epidemiology and pathogenesis of coronavirus disease (COVID-19)

$218 \quad$ outbreak. J. Autoimmun. 102433 (2020). doi:10.1016/j.jaut.2020.102433

219 5. CDC. People Who Are At Higher Risk. Available at: https://www.cdc.gov/coronavirus/2019-ncov/needextra-precautions/people-at-higher-risk.html. (Accessed: 29th April 2020)

221 6. Shikha Garg, MD1,*; Lindsay Kim, MD1,*; Michael Whitaker, MPH1, 2; Alissa O’Halloran, MSPH1; 222 Charisse Cummings, MPH1, 3; Rachel Holstein, MPH1, 4; Mila Prill, MSPH1; Shua J. Chai, MD1; Pam D. Kirley, MPH5; Nisha B. Alden, MPH6; Breanna Kawasaki, MPH6; Kim, M. Hospitalization Rates and Characteristics of Patients Hospitalized with Laboratory-Confirmed Coronavirus Disease 2019 - COVIDNET, 14 States, March 1-30, 2020. 69,(2020).

226 7. Chidambaram, P. State Reporting of Cases and Deaths Due to COVID-19 in Long-Term Care Facilities. Kaiser Family Foundation Available at: https://www.kff.org/medicaid/issue-brief/state-reporting-of-casesand-deaths-due-to-covid-19-in-long-term-care-facilities/?utm_campaign=KFF-2020Medicaid\&utm_source=hs_email\&utm_medium=email\&utm_content=2\&_hsenc=p2ANqtz-

8. Kaiser Family Foundation. More than 10,000 People in Long-Term Care Facilities Have Died Due to COVID-19. Available at: https://www.kff.org/medicaid/press-release/more-than-10000-people-in-long-

$2349 . \quad$ Reichard, A., Stolzle, H. \& Fox, M. H. Health disparities among adults with physical disabilities or 
medRxiv preprint doi: https://doi.org/10.1101/2020.06.24.20139212; this version posted June 26, 2020. The copyright holder for this preprint (which was not certified by peer review) is the author/funder, who has granted medRxiv a license to display the preprint in perpetuity.

It is made available under a CC-BY-ND 4.0 International license .

237 10. Havercamp, S. M., Scandlin, D. \& Roth, M. Health disparities among adults with developmental disabilities, adults with other disabilities, and adults not reporting disability in North Carolina. Public Health Rep. 119, $418-426$ (2004).

240 11. Pulrang, A. COVID-19 Teaches Us A Lot About Differences In The Disability Community. (2020). Available at: https://www.forbes.com/sites/andrewpulrang/2020/04/30/covid-19-teaches-us-a-lot-aboutdifferences-in-the-disability-community/\#1d756a6b7714. (Accessed: 29th April 2020)

243 12. United States Census. DISABILITY CHARACTERISTICS. Available at: https://data.census.gov/cedsci/table?q=Disability\&tid=ACSST1Y2018.S1810\&t=Disability\&y=2018\&g=01 00000US.050000\&layer=VT_2018_050_00_PY_D1\&hidePreview=true. (Accessed: 30th April 2020)

13. United States Census. Explore Census Data. Available at: https://data.census.gov/cedsci/. (Accessed: 12th

14. Coronavirus Locations: COVID-19 Map by County and State. Available at: https://usafacts.org/visualizations/coronavirus-covid-19-spread-map/. (Accessed: 12th April 2020)

15. Google. See how your community is moving around differently due to COVID-19. Available at: https://www.google.com/covid19/mobility/. (Accessed: 12th April 2020)

252 16. Social Security. Disability Evaluation Under Social Security. Available at: https://www.ssa.gov/disability/professionals/bluebook/general-info.htm. (Accessed: 29th April 2020)

254 17. CDC. Principles of Public Health Practice, Third Edition. Available at: https://www.cdc.gov/csels/dsepd/ss1978/lesson3/section2.html. (Accessed: 10th June 2020)

18. IBM. Downloading IBM SPSS Statistics 25. Ibm (2020). Available at: https://www.ibm.com/analytics/spss-

258 19. The R Foundation. The R Project for Statistical Computing. Http://Www.R-Project.Org/ 1-12 (2018).

259 20. Tobergte, D. R. \& Curtis, S. Disability and Health in the United States, 2001-2005. J. Chem. Inf. Model. 53, $260 \quad 1689-1699(2013)$.

261 21. Froehlich-Grobe, Katherine and Lollar, D. Obesity and Disability: Time to Act. Am. J. Prev. Med. 41, 541$262545(2011)$.

263 22. Brian S. Armour, PhD Charles Adam Brush, MSW, MPH Vincent A. Campbell, PhD John E. Crews, MA, 
medRxiv preprint doi: https://doi.org/10.1101/2020.06.24.20139212; this version posted June 26, 2020. The copyright holder for this preprint (which was not certified by peer review) is the author/funder, who has granted medRxiv a license to display the preprint in perpetuity.

It is made available under a CC-BY-ND 4.0 International license .

Roland Richard, MPH Mark E. Swanson, MD, MPH Candice Jalonen Swartwood, and D. L. Disability and Health State Chartbook. Profiles of Health for Adults With Disabilities. Cent. DI (2006).

267 23. Krahn, G. L., Walker, D. K. \& Correa-De-Araujo, R. Persons with disabilities as an unrecognized health disparity population. Am. J. Public Health 105, S198-S206 (2015).

24. Reichard, A. \& Stolzle, H. Diabetes among adults with cognitive limitations compared to individuals with no cognitive disabilities. Intellect. Dev. Disabil. 49, 141-154 (2011).

271 25. Pineda, V. S. \& Corburn, J. Disability, Urban Health Equity, and the Coronavirus Pandemic: Promoting Cities for All. J. Urban Heal. (2020). doi:10.1007/s11524-020-00437-7

273 26. Weise, Karen and Baker, M. Chilling' Plans: Who Gets Care as Washington State Hospitals Fill Up? The New York Times Available at: https://www.nytimes.com/2020/03/20/us/coronavirus-in-seattle-washington-

27. Turk, M. A., Landes, S. D., Formica, M. K. \& Goss, K. D. Intellectual and developmental disability and COVID-19 case-fatality trends: TriNetX analysis. Disabil. Health J. 100942 (2020). doi:10.1016/j.dhjo.2020.100942 severe disability among community-dwelling older adults with functional limitations. J. Appl. Gerontol. 26, $258-273$ (2007).

29. Control, C. for D. People With Disabilities. Available at: https://www.cdc.gov/coronavirus/2019-ncov/need-

284 30. Hauthal, N., Sandmann, P., Debener, S. \& Thome, J. D. Visual movement perception in deaf and hearing individuals. Adv. Cogn. Psychol. 9, 53-61 (2013).

31. Campbell, V. A., Gilyard, J. A., Sinclair, L., Sternberg, T. \& Kailes, J. I. Preparing for and responding to pandemic influenza: Implications for people with disabilities. Am. J. Public Health 99, 294-300 (2009).

32. United States Census. Anniversary of Americans With Disabilities Act: July 26, 2019. Available at:

290 33. Colby, S. L. \& Ortman, J. M. The Baby Boom Cohort in the United States : 2012 to 2060. US Census Bur. $291 \quad 16$ (2014). doi:P25-1141

292 34. Control, C. for D. Disability Impacts All of Us. Available at: 
medRxiv preprint doi: https://doi.org/10.1101/2020.06.24.20139212; this version posted June 26, 2020. The copyright holder for this preprint (which was not certified by peer review) is the author/funder, who has granted medRxiv a license to display the preprint in perpetuity. It is made available under a CC-BY-ND 4.0 International license.

293 https://www.cdc.gov/ncbddd/disabilityandhealth/infographic-disability-impacts-all.html. (Accessed: 26th

294

May 2020)

295

296

297 
medRxiv preprint doi: https://doi.org/10.1101/2020.06.24.20139212; this version posted June 26, 2020. The copyright holder for this preprint (which was not certified by peer review) is the author/funder, who has granted medRxiv a license to display the preprint in perpetuity.

It is made available under a CC-BY-ND 4.0 International license.

\section{Figure and Table Legends:}

299 Table 1. Description of Data Elements

300 Table 2. Independent sample t-test comparing counties with a higher and lower median death rate

301 Table 3. Independent sample t-test comparing counties with a higher and lower median infection rate

302 Figure 1. Death due to SARS-CoV-2 when controlled for state and median income

303 Figure 2. Infection due to SARS-CoV-2 when controlled for the state and median income

305 Table S1. Independent sample t-test with comprehensive summary statistics comparing counties data element:

306 mean, minimum, maximum, confidence interval lower and upper bound

307 Table S2. Detailed results of the bivariate analysis of risk of death by SARS-CoV-2 when controlled for state, 308 and median income

309 Table S3. Detailed results of the bivariate analysis of the risk of death by SARS-CoV-2 when controlled for 310 the state, median income, and total population

311 Table S4. Detailed results of the bivariate analysis of the risk of infection by SARS-CoV-2 when controlled

312 for state, and median income

313 Table S5. Detailed results of the bivariate analysis of the rate of infection by SARS-CoV-2 when controlled

314 for the state, median income, and total population

315

316 Figure S1. Death due to SARS-CoV-2 controlled for state, median income and total population

317 Figure S2. Infection due to SARS-CoV-2 controlled for the state, median income and total population 
medRxiv preprint doi: https://doi.org/10.1101/2020.06.24.20139212; this version posted June 26, 2020. The copyright holder for this preprint (which was not certified by peer review) is the author/funder, who has granted medRxiv a license to display the preprint in perpetuity.

It is made available under a CC-BY-ND 4.0 International license .

Table 1: Description of Data Elements

\begin{tabular}{|c|c|}
\hline Data Elements & Description \\
\hline Total population & Total population \\
\hline SARS-CoV-2 infection rate & Rate of SARS-CoV-2 infection in one per million \\
\hline $\begin{array}{l}\text { SARS-CoV-2 infection death } \\
\text { rate }\end{array}$ & Rate of SARS-CoV-2 infection related death (percent) \\
\hline Retail mobility & Google retail recreation mobility \\
\hline Grocery mobility & Google grocery pharmacy mobility \\
\hline Park mobility & Google parks mobility \\
\hline Transit mobility & Google transit mobility \\
\hline Work mobility & Google workplace mobility \\
\hline Resident mobility & Google residential mobility \\
\hline Black male & Percent Black alone male \\
\hline Black female & Percent Black alone female \\
\hline Asian male & Percent Asian alone male \\
\hline Asian female & Percent Asian alone female \\
\hline White male & Percent Non-Hispanic White alone male \\
\hline White female & Percent Non-Hispanic White alone female \\
\hline Hispanic male & Percent Hispanic male \\
\hline Hispanic female & Percent Hispanic female \\
\hline Median income & Median family income; past 12 months 2018 \\
\hline Poverty & $\begin{array}{l}\text { Percent below poverty level population for whom poverty } \\
\text { status is determined }\end{array}$ \\
\hline High school & $\begin{array}{l}\text { Percent below poverty level population for whom poverty } \\
\text { status is determined RACE and HISPANIC OR LATINO ORIGIN } \\
\text { White alone }\end{array}$ \\
\hline Bachelors & $\begin{array}{l}\text { Percent population } 25 \text { years and over bachelor's degree or } \\
\text { higher }\end{array}$ \\
\hline Insured male & $\begin{array}{l}\text { Percent insured civilian noninstitutionalized population SEX } \\
\text { male }\end{array}$ \\
\hline Insured female & $\begin{array}{l}\text { Percent insured civilian noninstitutionalized population SEX } \\
\text { female }\end{array}$ \\
\hline Insured Black & $\begin{array}{l}\text { Percent insured civilian noninstitutionalized population RACE } \\
\text { and HISPANIC OR LATINO ORIGIN Black or African American } \\
\text { alone }\end{array}$ \\
\hline
\end{tabular}


medRxiv preprint doi: https://doi.org/10.1101/2020.06.24.20139212; this version posted June 26, 2020. The copyright holder for this preprint (which was not certified by peer review) is the author/funder, who has granted medRxiv a license to display the preprint in perpetuity.

\begin{tabular}{|c|c|}
\hline Insured Asian & $\begin{array}{l}\text { Percent insured civilian noninstitutionalized population RACE } \\
\text { and HISPANIC OR LATINO ORIGIN ASIAN alone }\end{array}$ \\
\hline Insured Hispanic & $\begin{array}{l}\text { Percent insured civilian noninstitutionalized population RACE } \\
\text { and HISPANIC OR LATINO ORIGIN Hispanic or Latino of any } \\
\text { race }\end{array}$ \\
\hline Insured White alone & $\begin{array}{l}\text { Percent insured civilian noninstitutionalized population RACE } \\
\text { and HISPANIC OR LATINO ORIGIN White alone not Hispanic or } \\
\text { Latino }\end{array}$ \\
\hline Medicaid & $\begin{array}{l}\text { Percent public coverage Medicaid means tested public } \\
\text { coverage alone or in combination }\end{array}$ \\
\hline Disability & $\begin{array}{l}\text { Percent with a disability total civilian non-institutionalized } \\
\text { population }\end{array}$ \\
\hline Disability male & Percent with a disability SEX Male \\
\hline Disability female & Percent with a disability SEX Female \\
\hline Disability Black & $\begin{array}{l}\text { Percent with a disability RACE AND HISPANIC OR LATINO } \\
\text { ORIGIN Black or African American }\end{array}$ \\
\hline Disability Asian & $\begin{array}{l}\text { Percent with a disability RACE AND HISPANIC OR LATINO } \\
\text { ORIGIN Asian alone }\end{array}$ \\
\hline Disability White & $\begin{array}{l}\text { Percent with a disability RACE AND HISPANIC OR LATINO } \\
\text { ORIGIN White alone, not Hispanic or Latino }\end{array}$ \\
\hline Disability Hispanic & $\begin{array}{l}\text { Percent with a disability RACE AND HISPANIC OR LATINO } \\
\text { ORIGIN Hispanic or Latino (of any race) }\end{array}$ \\
\hline Disability 5 to 17 years & Percent with a disability AGE 5 to 17 years \\
\hline Disability 18 to 34 years & Percent with a disability AGE 18 to 34 years \\
\hline Disability 35 to 64 years & Percent with a disability AGE 35 to 64 years \\
\hline Disability 65 to 74 years & Percent with a disability AGE 65 to 74 years \\
\hline Disability 75 years and over & Percent with a disability AGE 75 years \\
\hline Disability hearing difficulty & Percent with a disability with a hearing difficulty \\
\hline Disability vision difficulty & Percent with a disability with a vision difficulty \\
\hline Disability cognitive difficulty & Percent with a disability with a cognitive difficulty \\
\hline Disability ambulatory difficulty & Percent with disability with an ambulatory difficulty \\
\hline Disability self-care difficulty & Percent with a disability with self-care difficulty \\
\hline Disability independent living & Percent with a disability with independent living difficulty \\
\hline
\end{tabular}


Table 2: Independent sample t-test comparing counties with higher and lower median death rate

\begin{tabular}{|c|c|c|c|c|c|c|c|}
\hline \multirow[t]{2}{*}{ Data Elements } & \multicolumn{2}{|c|}{ Total } & \multicolumn{2}{|c|}{$\begin{array}{l}\text { Group 1: SARS-CoV-2 } \\
\text { death rate } \geq 3.4\end{array}$} & \multicolumn{2}{|c|}{$\begin{array}{c}\text { Group 2: SARS-CoV-2 } \\
\text { death rate }<3.4\end{array}$} & \multirow[t]{2}{*}{ Significance } \\
\hline & Mean $^{+}$ & $\begin{array}{c}\text { Std. } \\
\text { Deviation }\end{array}$ & Mean $^{+}$ & $\begin{array}{c}\text { Std. } \\
\text { Deviation }\end{array}$ & Mean $^{+}$ & $\begin{array}{c}\text { Std. } \\
\text { Deviation }\end{array}$ & \\
\hline Total population & 276905.47 & 683001.80 & 295707.40 & 476086.20 & 605705.70 & 1113765.30 & $9.9 \mathrm{E}-03$ \\
\hline SARS-CoV-2 infection Rate* & 1593.00 & 2768.90 & 2483.40 & 3390.40 & 2306.30 & 3275.70 & 7.0E-01 \\
\hline Retail mobility & -0.46 & 0.16 & -0.46 & 0.14 & -0.52 & 0.11 & $1.9 \mathrm{E}-03$ \\
\hline Grocery mobility & -0.16 & 0.15 & -0.16 & 0.13 & -0.20 & 0.14 & 3.3E-02 \\
\hline Park mobility & 0.05 & 0.59 & 0.02 & 0.60 & 0.21 & 0.61 & $5.3 \mathrm{E}-02$ \\
\hline Transit mobility & -0.47 & 0.20 & -0.48 & 0.21 & -0.48 & 0.20 & 9.7E-01 \\
\hline Work mobility & -0.37 & 0.10 & -0.38 & 0.09 & -0.40 & 0.07 & 7.5E-02 \\
\hline Resident mobility & 0.14 & 0.06 & 0.15 & 0.06 & 0.14 & 0.04 & 8.1E-02 \\
\hline Black male & 5.30 & 6.60 & 7.30 & 7.40 & 5.20 & 4.60 & $1.6 \mathrm{E}-02$ \\
\hline Black female & 4.90 & 6.90 & 7.30 & 8.00 & 5.40 & 5.30 & 4.3E-02 \\
\hline Asian male & 1.50 & 2.50 & 1.65 & 2.35 & 2.80 & 3.50 & $6.2 \mathrm{E}-03$ \\
\hline Asian female & 1.60 & 2.70 & 1.80 & 2.50 & 3.10 & 3.80 & $5.8 \mathrm{E}-03$ \\
\hline White male & 37.10 & 9.90 & 34.00 & 10.70 & 33.30 & 9.50 & $6.3 \mathrm{E}-01$ \\
\hline White female & 37.60 & 10.00 & 34.70 & 10.80 & 34.70 & 10.80 & $9.4 \mathrm{E}-01$ \\
\hline Hispanic male & 5.20 & 6.70 & 6.00 & 8.10 & 7.20 & 6.90 & 2.3E-01 \\
\hline Hispanic female & 4.80 & 6.60 & 5.80 & 8.10 & 7.00 & 6.80 & 2.4E-01 \\
\hline Median income & 69910.10 & 19295.80 & 69778.60 & 19887.00 & 83430.40 & 20397.10 & $2.0 \mathrm{E}-06$ \\
\hline Poverty & 15.10 & 5.80 & 16.00 & 5.70 & 12.70 & 4.70 & $5.0 \mathrm{E}-06$ \\
\hline High school & 87.60 & 5.50 & 86.40 & 6.10 & 88.60 & 4.70 & 3.0E-03 \\
\hline Bachelors & 24.70 & 10.80 & 24.50 & 10.80 & 31.80 & 10.90 & $2.0 \mathrm{E}-06$ \\
\hline Insured male & 91.50 & 3.40 & 91.10 & 3.20 & 92.50 & 3.00 & $1.5 \mathrm{E}-03$ \\
\hline Insured female & 93.60 & 3.00 & 93.20 & 3.10 & 94.40 & 2.50 & $2.8 \mathrm{E}-03$ \\
\hline Insured Black & 91.30 & 6.30 & 90.40 & 6.40 & 92.20 & 3.00 & $1.2 \mathrm{E}-02$ \\
\hline Insured Asian & 90.30 & 12.20 & 90.00 & 11.10 & 92.50 & 4.20 & $2.9 \mathrm{E}-02$ \\
\hline Insured Hispanic & 86.00 & 10.30 & 84.80 & 9.70 & 86.00 & 7.40 & 3.0E-01 \\
\hline Insured White alone & 93.90 & 2.70 & 93.80 & 2.60 & 95.30 & 2.00 & $1.0 \mathrm{E}-05$ \\
\hline Medicaid & 23.20 & 6.60 & 24.30 & 7.30 & 20.60 & 6.40 & 1.7E-04 \\
\hline Disability & 15.00 & 3.70 & 14.30 & 3.30 & 12.90 & 3.00 & $8.1 \mathrm{E}-04$ \\
\hline Disability male & 13.10 & 3.10 & 13.10 & 3.30 & 12.30 & 2.80 & $1.4 \mathrm{E}-01$ \\
\hline Disability female & 13.40 & 2.80 & 13.50 & 2.80 & 12.80 & 2.60 & $1.3 \mathrm{E}-01$ \\
\hline
\end{tabular}




\begin{tabular}{|c|c|c|c|c|c|c|c|}
\hline Disability Black & 15.40 & 6.10 & 15.50 & 4.70 & 14.80 & 6.40 & $4.9 \mathrm{E}-01$ \\
\hline Disability Asian & 7.90 & 3.90 & 7.30 & 3.00 & 7.80 & 4.10 & $5.2 \mathrm{E}-01$ \\
\hline Disability White & 14.00 & 2.85 & 14.20 & 3.10 & 13.30 & 2.50 & $5.0 \mathrm{E}-02$ \\
\hline Disability Hispanic & 11.40 & 4.90 & 11.70 & 6.10 & 11.10 & 4.20 & $5.2 \mathrm{E}-01$ \\
\hline Disability 5 to 17 years & 6.30 & 2.50 & 6.30 & 2.80 & 6.00 & 2.00 & $4.8 \mathrm{E}-01$ \\
\hline Disability 18 to 34 years & 7.10 & 2.30 & 7.20 & 2.30 & 6.70 & 2.20 & $1.4 \mathrm{E}-01$ \\
\hline Disability 35 to 64 years & 13.00 & 3.90 & 13.20 & 4.00 & 12.00 & 3.60 & $2.9 \mathrm{E}-02$ \\
\hline Disability 65 to 74 years & 23.30 & 5.20 & 23.60 & 5.50 & 22.60 & 5.00 & $2.4 \mathrm{E}-01$ \\
\hline Disability 75 years and over & 47.10 & 6.00 & 47.80 & 6.70 & 46.70 & 5.60 & $2.6 \mathrm{E}-01$ \\
\hline Disability hearing difficulty & 3.70 & 1.10 & 3.50 & 1.10 & 3.50 & 0.88 & $7.0 \mathrm{E}-01$ \\
\hline Disability vision difficulty & 2.20 & 0.77 & 2.30 & 0.89 & 2.10 & 0.67 & $1.5 \mathrm{E}-01$ \\
\hline Disability cognitive difficulty & 5.40 & 1.40 & 5.50 & 1.50 & 5.20 & 1.30 & $1.9 \mathrm{E}-01$ \\
\hline Disability ambulatory & 7.00 & 1.70 & 7.10 & 1.70 & 6.60 & 1.60 \\
\hline difficulty & & & & & & $6.3 \mathrm{E}-02$ \\
\hline Disability self-care difficulty & 2.70 & 0.71 & 2.80 & 0.63 & 2.70 & 0.64 \\
\hline Disability independent living & 6.10 & 1.40 & 6.10 & 1.30 & 5.90 & 1.30 \\
\hline difficulty & & & & & & $1.6 \mathrm{E}-01$ \\
\hline
\end{tabular}

+ All reported numbers are in percent except total population, SARS-CoV-2 infection rate, and median income.

* Rate of SARS-CoV-2 infection in one per Million 
Table 3: Independent sample t-test comparing counties with higher and lower median infection rate

\begin{tabular}{|c|c|c|c|c|c|c|c|}
\hline \multirow[t]{2}{*}{ Data Elements } & \multicolumn{2}{|c|}{ Total (N:352) } & \multicolumn{2}{|c|}{$\begin{array}{c}\text { Group 1: SARS-CoV-2 Infection } \\
\text { Rate } \geq 555.6^{*}\end{array}$} & \multicolumn{2}{|c|}{$\begin{array}{l}\text { Group 2: SARS-CoV-2 } \\
\text { Infection Rate }<555.6^{*}\end{array}$} & \multirow[t]{2}{*}{ Significance } \\
\hline & Mean $^{+}$ & $\begin{array}{l}\text { Std. } \\
\text { Deviation }\end{array}$ & Mean ${ }^{+}$ & Std. Deviation & Mean $^{+}$ & $\begin{array}{c}\text { Std. } \\
\text { Deviation }\end{array}$ & \\
\hline Total population & 276905.47 & 683001.80 & 382607.10 & 858300.10 & 196740.20 & 468817.40 & $1.2 \mathrm{E}-02$ \\
\hline SARS-CoV-2 death Rate & 3.83 & 2.20 & 3.50 & 2.00 & 4.60 & 2.60 & 5.0E-03 \\
\hline Retail mobility & -0.46 & 0.16 & -0.49 & 0.15 & -0.44 & 0.15 & 3.0E-03 \\
\hline Grocery mobility & -0.16 & 0.15 & -0.17 & 0.14 & -0.14 & 0.13 & $9.1 \mathrm{E}-02$ \\
\hline Park mobility & 0.05 & 0.59 & 0.24 & 0.52 & -0.20 & 0.57 & $6.4 \mathrm{E}-08$ \\
\hline Transit mobility & -0.47 & 0.20 & -0.47 & 0.21 & 0.47 & 0.17 & 8.6E-01 \\
\hline Work mobility & -0.37 & 0.10 & -0.39 & 0.09 & -0.36 & 0.07 & $3.1 \mathrm{E}-02$ \\
\hline Resident mobility & 0.14 & 0.06 & 0.15 & 0.06 & 0.14 & 0.06 & 5.7E-01 \\
\hline Black male & 5.30 & 6.60 & 8.20 & 7.30 & 2.60 & 4.30 & $1.8 \mathrm{E}-16$ \\
\hline Black female & 4.90 & 6.90 & 8.20 & 7.70 & 1.90 & 3.90 & $1.8 \mathrm{E}-19$ \\
\hline Asian male & 1.50 & 2.50 & 1.90 & 2.90 & 1.20 & 2.10 & 1.0E-02 \\
\hline Asian female & 1.60 & 2.70 & 2.00 & 3.10 & 1.30 & 2.30 & $1.5 \mathrm{E}-02$ \\
\hline White male & 37.10 & 9.90 & 34.20 & 8.70 & 39.40 & 10.40 & 5.3E-07 \\
\hline White female & 37.60 & 10.00 & 35.10 & 9.10 & 39.70 & 10.50 & $1.4 \mathrm{E}-05$ \\
\hline Hispanic male & 5.20 & 6.70 & 4.70 & 4.60 & 5.80 & 8.40 & 1.3E-01 \\
\hline Hispanic female & 4.80 & 6.60 & 4.50 & 4.70 & 5.40 & 8.20 & $2.2 \mathrm{E}-01$ \\
\hline Median income & 69910.10 & 19295.80 & 76027.50 & 22996.80 & 65111.50 & 12876.50 & 8.9E-08 \\
\hline Poverty & 15.10 & 5.80 & 14.90 & 6.30 & 15.30 & 5.10 & 5.1E-01 \\
\hline High school & 87.60 & 5.50 & 87.40 & 5.40 & 87.60 & 5.60 & 7.9E-01 \\
\hline Bachelors & 24.70 & 10.80 & 28.10 & 12.30 & 21.90 & 8.10 & $4.3 \mathrm{E}-08$ \\
\hline Insured male & 91.50 & 3.40 & 91.50 & 3.70 & 91.50 & 2.70 & 7.7E-01 \\
\hline Insured female & 93.60 & 3.00 & 93.60 & 3.30 & 93.70 & 2.60 & $6.2 \mathrm{E}-01$ \\
\hline Insured Black & 91.30 & 6.30 & 90.70 & 5.50 & 91.80 & 6.90 & $9.7 \mathrm{E}-02$ \\
\hline Insured Asian & 90.30 & 12.20 & 90.00 & 13.10 & 90.10 & 11.50 & $9.5 \mathrm{E}-01$ \\
\hline Insured Hispanic & 86.00 & 10.30 & 84.20 & 10.60 & 87.50 & 9.10 & 2.7E-03 \\
\hline Insured White alone & 93.90 & 2.70 & 94.20 & 2.90 & 93.70 & 2.30 & 1.0E-01 \\
\hline Medicaid & 23.20 & 6.60 & 22.30 & 6.60 & 24.00 & 6.40 & $1.4 \mathrm{E}-02$ \\
\hline Disability & 15.00 & 3.70 & 14.10 & 3.70 & 15.60 & 3.40 & 2.3E-04 \\
\hline Disability male & 13.10 & 3.10 & 12.60 & 3.10 & 13.80 & 3.00 & $6.2 \mathrm{E}-03$ \\
\hline Disability female & 13.40 & 2.80 & 13.10 & 2.80 & 13.80 & 2.80 & $8.6 \mathrm{E}-02$ \\
\hline Disability Black & 15.40 & 6.10 & 14.80 & 6.20 & 16.90 & 5.50 & 6.7E-02 \\
\hline
\end{tabular}




\begin{tabular}{|c|c|c|c|c|c|c|c|}
\hline Disability Asian & 7.90 & 3.90 & 7.60 & 4.00 & 8.50 & 3.60 & $2.5 \mathrm{E}-01$ \\
\hline Disability White & 14.00 & 2.85 & 13.20 & 2.70 & 15.20 & 2.60 & $6.9 \mathrm{E}-07$ \\
\hline Disability Hispanic & 11.40 & 4.90 & 11.60 & 5.00 & 11.00 & 5.00 & $3.9 \mathrm{E}-01$ \\
\hline Disability 5 to 17 years & 6.30 & 2.50 & 6.40 & 2.40 & 6.20 & 2.70 & $6.7 \mathrm{E}-01$ \\
\hline Disability 18 to 34 years & 7.10 & 2.30 & 6.90 & 2.20 & 7.50 & 2.50 & $1.0 \mathrm{E}-01$ \\
\hline Disability 35 to 64 years & 13.00 & 3.90 & 12.50 & 4.10 & 13.70 & 3.50 & $2.3 \mathrm{E}-02$ \\
\hline Disability 65 to 74 years & 23.30 & 5.20 & 22.40 & 5.30 & 24.70 & 4.80 & $2.3 \mathrm{E}-03$ \\
\hline $\begin{array}{l}\text { Disability } 75 \text { years and } \\
\text { over }\end{array}$ & 47.10 & 6.00 & 46.60 & 6.20 & 47.70 & 5.60 & $1.8 \mathrm{E}-01$ \\
\hline $\begin{array}{l}\text { Disability hearing } \\
\text { difficulty }\end{array}$ & 3.70 & 1.10 & 3.40 & 0.96 & 4.10 & 1.10 & $9.0 \mathrm{E}-06$ \\
\hline Disability vision difficulty & 2.20 & 0.77 & 2.20 & 0.78 & 2.30 & 0.74 & $2.3 \mathrm{E}-01$ \\
\hline $\begin{array}{l}\text { Disability cognitive } \\
\text { difficulty }\end{array}$ & 5.40 & 1.40 & 5.30 & 1.50 & 5.50 & 1.30 & $3.0 \mathrm{E}-01$ \\
\hline $\begin{array}{l}\text { Disability ambulatory } \\
\text { difficulty }\end{array}$ & 7.00 & 1.70 & 6.80 & 1.70 & 7.20 & 1.60 & $1.3 \mathrm{E}-01$ \\
\hline $\begin{array}{l}\text { Disability self-care } \\
\text { difficulty }\end{array}$ & 2.70 & 0.71 & 2.80 & 0.70 & 6.00 & 1.40 & $8.3 \mathrm{E}-01$ \\
\hline $\begin{array}{l}\text { Disability independent } \\
\text { living difficulty }\end{array}$ & 6.10 & 1.40 & 6.00 & 1.40 & 6.20 & 1.30 & $4.2 \mathrm{E}-01$ \\
\hline
\end{tabular}

+ All reported numbers are in percent except total population, SARS-CoV-2 infection rate, and median income.

* Rate of SARS-CoV-2 infection in one per Million 
Table S5: Detailed results of the bivariate analysis of the rate of infection by SARS-CoV- 2 when controlled for the state, median income, and total population

\begin{tabular}{|c|c|c|c|c|c|c|c|}
\hline Risk Factors & Estimate & $\begin{array}{l}\text { Standard } \\
\text { Error }\end{array}$ & Statistic & $p$-value & Conf.low & Conf.high & Estimate_95CI \\
\hline Disability & $-8.40 \mathrm{E}-02$ & 8.27E-02 & $-1.02 E+00$ & $3.11 \mathrm{E}-01$ & $-2.47 \mathrm{E}-01$ & 7.91E-02 & $-0.08(-0.25-0.08)$ \\
\hline Disability male & $-8.90 E-02$ & $9.70 \mathrm{E}-02$ & $-9.21 E-01$ & 3.59E-01 & $-2.81 \mathrm{E}-01$ & $1.02 \mathrm{E}-01$ & $-0.09(-0.28-0.10)$ \\
\hline Disability female & $-1.60 \mathrm{E}-02$ & $9.34 \mathrm{E}-02$ & $-1.72 \mathrm{E}-01$ & 8.64E-01 & $-2.01 \mathrm{E}-01$ & $1.69 \mathrm{E}-01$ & $-0.02(-0.20-0.17)$ \\
\hline Disability Black & $-1.14 \mathrm{E}-01$ & 8.94E-02 & $-1.28 \mathrm{E}+00$ & 2.04E-01 & $-2.92 \mathrm{E}-01$ & $6.32 \mathrm{E}-02$ & $-0.11(-0.29-0.06)$ \\
\hline Disability Asian & $1.40 \mathrm{E}-01$ & 1.09E-01 & $1.28 \mathrm{E}+00$ & 2.05E-01 & $-7.81 \mathrm{E}-02$ & $3.58 \mathrm{E}-01$ & $0.14(-0.08-0.36)$ \\
\hline Disability White alone & $-5.80 \mathrm{E}-02$ & 1.01E-01 & $-5.70 \mathrm{E}-01$ & 5.69E-01 & $-2.58 \mathrm{E}-01$ & $1.43 \mathrm{E}-01$ & $-0.06(-0.26-0.14)$ \\
\hline Disability Hispanic & $-7.00 \mathrm{E}-03$ & $8.94 \mathrm{E}-02$ & $-8.28 \mathrm{E}-02$ & $9.34 \mathrm{E}-01$ & $-1.85 \mathrm{E}-01$ & $1.70 \mathrm{E}-01$ & $-0.01(-0.19-0.17)$ \\
\hline Disability 5 to 17 Years & $7.80 \mathrm{E}-02$ & 7.46E-02 & $1.04 \mathrm{E}+00$ & 2.99E-01 & $-6.98 \mathrm{E}-02$ & $2.25 \mathrm{E}-01$ & $0.08(-0.07-0.23)$ \\
\hline Disability 18 to 34 Years & $-1.40 \mathrm{E}-01$ & $7.84 \mathrm{E}-02$ & $-1.78 \mathrm{E}+00$ & 7.71E-02 & $-2.95 \mathrm{E}-01$ & $1.54 \mathrm{E}-02$ & $-0.14(-0.30-0.02)$ \\
\hline Disability 35 to 64 Years & $-6.30 \mathrm{E}-02$ & $1.02 \mathrm{E}-01$ & $-6.13 \mathrm{E}-01$ & $5.41 \mathrm{E}-01$ & $-2.65 \mathrm{E}-01$ & $1.40 \mathrm{E}-01$ & $-0.06(-0.265-0.14)$ \\
\hline Disability 65 to 74 Years & $-1.10 \mathrm{E}-02$ & 8.94E-02 & $-1.18 \mathrm{E}-01$ & $9.06 \mathrm{E}-01$ & $-1.87 \mathrm{E}-01$ & $1.66 \mathrm{E}-01$ & $-0.01(-0.19-0.17)$ \\
\hline Disability 75 Years and Over & 7.10E-02 & 7.25E-02 & 9.82E-01 & $3.28 \mathrm{E}-01$ & $-7.22 \mathrm{E}-02$ & $2.15 \mathrm{E}-01$ & $0.07(-0.07-0.22)$ \\
\hline Disability hearing difficulty & $-8.80 \mathrm{E}-02$ & $8.40 E-02$ & $-1.05 E+00$ & 2.97E-01 & $-2.54 \mathrm{E}-01$ & $7.82 \mathrm{E}-02$ & $-0.09(-0.25-0.08)$ \\
\hline Disability vision difficulty & $1.20 \mathrm{E}-02$ & 7.96E-02 & $1.46 \mathrm{E}-01$ & $8.84 \mathrm{E}-01$ & $-1.46 \mathrm{E}-01$ & $1.69 \mathrm{E}-01$ & $0.01(-0.15-0.17)$ \\
\hline Disability cognitive difficulty & $-7.00 \mathrm{E}-02$ & $8.96 \mathrm{E}-02$ & $-7.83 \mathrm{E}-01$ & 4.35E-01 & $-2.47 \mathrm{E}-01$ & $1.07 \mathrm{E}-01$ & $-0.07(-0.25-0.11)$ \\
\hline Disability ambulatory difficulty & $3.50 \mathrm{E}-02$ & $9.06 \mathrm{E}-02$ & 3.87E-01 & 7.00E-01 & $-1.44 \mathrm{E}-01$ & 2.14E-01 & $0.04(-0.14-0.21)$ \\
\hline Disability self-care difficulty & 4.90E-02 & 7.47E-02 & $6.52 \mathrm{E}-01$ & 5.15E-01 & $-9.91 \mathrm{E}-02$ & 1.97E-01 & $0.05(-0.10-0.20)$ \\
\hline $\begin{array}{l}\text { Disability independent living } \\
\text { difficulty }\end{array}$ & $6.50 \mathrm{E}-02$ & 7.89E-02 & 8.30E-01 & 4.08E-01 & $-9.05 E-02$ & 2.21E-01 & $0.07(-0.091-0.22)$ \\
\hline
\end{tabular}




\begin{tabular}{|c|c|c|c|c|c|c|c|}
\hline Risk Factors & Estimate & $\begin{array}{l}\text { Standard } \\
\text { error }\end{array}$ & Statistic & $p$-value & Conf.low & Conf.high & Estimate_95CI \\
\hline Disability & $-1.69 E-01$ & $8.64 \mathrm{E}-02$ & $-1.95 E+00$ & $5.24 \mathrm{E}-02$ & $-3.39 E-01$ & $1.78 \mathrm{E}-03$ & $-0.17(-0.34-0.002)$ \\
\hline Disability male & $-2.53 \mathrm{E}-01$ & $9.75 \mathrm{E}-02$ & $-2.60 E+00$ & $1.04 \mathrm{E}-02$ & $-4.46 \mathrm{E}-01$ & $-6.03 E-02$ & $-0.25(-0.45--0.06)$ \\
\hline Disability female & $-8.10 \mathrm{E}-02$ & $1.00 \mathrm{E}-01$ & $-8.02 E-01$ & 4.24E-01 & $-2.79 \mathrm{E}-01$ & $1.18 \mathrm{E}-01$ & $-0.08(-0.28-0.12)$ \\
\hline Disability Black & $-1.33 E-01$ & $9.67 E-02$ & $-1.37 E+00$ & $1.73 \mathrm{E}-01$ & $-3.24 \mathrm{E}-01$ & $5.91 \mathrm{E}-02$ & $-0.13(-0.32-0.06)$ \\
\hline Disability Asian & $6.90 \mathrm{E}-02$ & $1.16 \mathrm{E}-01$ & 5.93E-01 & $5.55 \mathrm{E}-01$ & $-1.62 \mathrm{E}-01$ & 3.00E-01 & $0.07(-0.16-0.3)$ \\
\hline Disability White alone & $-2.23 \mathrm{E}-01$ & $1.03 \mathrm{E}-01$ & $-2.15 E+00$ & $3.30 \mathrm{E}-02$ & $-4.27 \mathrm{E}-01$ & $-1.82 \mathrm{E}-02$ & $-0.22(-0.43--0.02)$ \\
\hline Disability Hispanic & $-7.60 \mathrm{E}-02$ & $9.63 \mathrm{E}-02$ & $-7.93 E-01$ & 4.29E-01 & $-2.67 \mathrm{E}-01$ & $1.14 \mathrm{E}-01$ & $-0.08(-0.27-0.11)$ \\
\hline Disability 5 to 17 Years & $-1.90 \mathrm{E}-02$ & $8.14 \mathrm{E}-02$ & $-2.33 E-01$ & 8.16E-01 & $-1.80 \mathrm{E}-01$ & $1.42 \mathrm{E}-01$ & $-0.02(-0.18-0.14)$ \\
\hline Disability 18 to 34 Years & $-2.52 E-01$ & $8.16 \mathrm{E}-02$ & $-3.09 E+00$ & $2.44 \mathrm{E}-03$ & $-4.13 E-01$ & $-9.05 E-02$ & $-0.25(-0.41--0.09)$ \\
\hline Disability 35 to 64 Years & $-7.80 \mathrm{E}-02$ & $1.11 \mathrm{E}-01$ & $-7.00 \mathrm{E}-01$ & $4.85 E-01$ & $-2.97 \mathrm{E}-01$ & $1.41 \mathrm{E}-01$ & $-0.08(-0.30-0.14)$ \\
\hline Disability 65 to 74 Years & $6.70 \mathrm{E}-02$ & $9.76 \mathrm{E}-02$ & $6.83 \mathrm{E}-01$ & $4.96 \mathrm{E}-01$ & $-1.26 \mathrm{E}-01$ & $2.60 \mathrm{E}-01$ & $0.07(-0.13-0.26)$ \\
\hline Disability 75 Years and Over & $1.20 \mathrm{E}-01$ & 7.94E-02 & $1.52 \mathrm{E}+00$ & $1.31 \mathrm{E}-01$ & $-3.65 E-02$ & $2.77 E-01$ & $0.12(-0.04-0.28)$ \\
\hline Disability hearing difficulty & $-2.63 E-01$ & 7.99E-02 & $-3.29 E+00$ & $1.25 \mathrm{E}-03$ & $-4.21 E-01$ & $-1.05 E-01$ & $-0.26(-0.42--0.11)$ \\
\hline Disability vision difficulty & $6.40 \mathrm{E}-02$ & $8.72 E-02$ & 7.38E-01 & 4.62E-01 & $-1.08 \mathrm{E}-01$ & $2.37 \mathrm{E}-01$ & $0.06(-0.108-0.24)$ \\
\hline Disability cognitive difficulty & $-1.22 \mathrm{E}-01$ & $9.78 \mathrm{E}-02$ & $-1.25 E+00$ & 2.14E-01 & $-3.15 E-01$ & $7.13 \mathrm{E}-02$ & $-0.12(-0.32-0.07)$ \\
\hline Disability ambulatory difficulty & $2.20 \mathrm{E}-02$ & $9.86 \mathrm{E}-02$ & 2.20E-01 & $8.26 \mathrm{E}-01$ & $-1.73 E-01$ & $2.17 E-01$ & $0.02(-0.17-0.22)$ \\
\hline Disability self-care difficulty & 1.15E-01 & $8.10 \mathrm{E}-02$ & $1.42 E+00$ & $1.59 \mathrm{E}-01$ & $-4.53 E-02$ & $2.75 \mathrm{E}-01$ & $0.12(-0.05-0.28)$ \\
\hline $\begin{array}{l}\text { Disability independent living } \\
\text { difficulty }\end{array}$ & 1.01E-01 & 8.64E-02 & $1.16 \mathrm{E}+00$ & 2.47E-01 & $-7.03 E-02$ & $2.71 E-01$ & $0.10(-0.07-0.27)$ \\
\hline
\end{tabular}


Table S3: Detailed results of the bivariate analysis of the risk of death by SARS-CoV-2 when controlled for the state, median income, and total population

\begin{tabular}{|c|c|c|c|c|c|c|c|}
\hline Risk Factors & Estimate & $\begin{array}{l}\text { Standard } \\
\text { Error }\end{array}$ & Statistic & $p$-value & Conf.low & Conf.high & Estimate_95Cl \\
\hline Disability & $5.30 \mathrm{E}-02$ & $1.05 \mathrm{E}-01$ & 5.03E-01 & $6.16 \mathrm{E}-01$ & $-1.54 \mathrm{E}-01$ & $2.59 \mathrm{E}-01$ & $0.05(-0.15-0.26)$ \\
\hline Disability male & $1.59 \mathrm{E}-01$ & 9.97E-02 & $1.60 \mathrm{E}+00$ & $1.12 \mathrm{E}-01$ & $-3.75 \mathrm{E}-02$ & $3.56 \mathrm{E}-01$ & $0.16(-0.04-0.36)$ \\
\hline Disability female & $1.48 \mathrm{E}-01$ & $9.73 E-02$ & $1.52 \mathrm{E}+00$ & $1.31 \mathrm{E}-01$ & $-4.46 \mathrm{E}-02$ & $3.40 \mathrm{E}-01$ & $0.15(-0.05-0.34)$ \\
\hline Disability Black & $1.11 \mathrm{E}-01$ & $7.28 \mathrm{E}-02$ & $1.53 \mathrm{E}+00$ & $1.30 \mathrm{E}-01$ & $-3.31 E-02$ & $2.55 \mathrm{E}-01$ & $0.11(-0.03-0.26)$ \\
\hline Disability Asian & $-6.00 E-02$ & $7.56 \mathrm{E}-02$ & $-7.90 \mathrm{E}-01$ & 4.32E-01 & $-2.10 \mathrm{E}-01$ & 9.07E-02 & $-0.06(-0.21-0.09)$ \\
\hline Disability Hispanic & $-3.30 E-02$ & 8.39E-02 & $-3.91 \mathrm{E}-01$ & $6.96 \mathrm{E}-01$ & $-1.99 E-01$ & $1.33 \mathrm{E}-01$ & $-0.03(-0.20-0.13)$ \\
\hline Disability 5 to 17 Years & $-5.70 \mathrm{E}-02$ & $8.11 \mathrm{E}-02$ & $-7.03 \mathrm{E}-01$ & 4.83E-01 & $-2.17 E-01$ & $1.03 \mathrm{E}-01$ & $-0.06(-0.22-0.10)$ \\
\hline Disability 18 to 34 Years & $1.95 \mathrm{E}-01$ & 8.19E-02 & $2.38 \mathrm{E}+00$ & $1.89 \mathrm{E}-02$ & $3.27 \mathrm{E}-02$ & 3.57E-01 & $0.20(0.03-0.36)$ \\
\hline Disability 35 to 64 Years & $1.46 \mathrm{E}-01$ & $1.06 \mathrm{E}-01$ & $1.37 \mathrm{E}+00$ & $1.72 \mathrm{E}-01$ & $-6.43 E-02$ & $3.56 \mathrm{E}-01$ & $0.15(-0.06-0.36)$ \\
\hline Disability 65 to 74 Years & 7.50E-02 & $9.46 \mathrm{E}-02$ & 7.91E-01 & 4.30E-01 & $-1.12 \mathrm{E}-01$ & $2.62 \mathrm{E}-01$ & $0.08(-0.11-0.26)$ \\
\hline Disability cognitive difficulty & $1.04 \mathrm{E}-01$ & $9.48 \mathrm{E}-02$ & $1.10 \mathrm{E}+00$ & $2.73 \mathrm{E}-01$ & $-8.30 \mathrm{E}-02$ & $2.92 \mathrm{E}-01$ & $0.10(-0.08-0.30)$ \\
\hline Disability ambulatory difficulty & 1.17E-01 & $9.51 \mathrm{E}-02$ & $1.23 \mathrm{E}+00$ & $2.21 \mathrm{E}-01$ & $-7.12 \mathrm{E}-02$ & 3.05E-01 & $0.12(-0.07-0.31)$ \\
\hline Disability self-care difficulty & 7.70E-02 & $7.82 \mathrm{E}-02$ & $9.84 \mathrm{E}-01$ & 3.27E-01 & $-7.76 \mathrm{E}-02$ & $2.32 \mathrm{E}-01$ & $0.08(-0.08-0.23)$ \\
\hline $\begin{array}{l}\text { Disability independent living } \\
\text { difficulty }\end{array}$ & $1.62 \mathrm{E}-01$ & $8.21 \mathrm{E}-02$ & $1.97 \mathrm{E}+00$ & $5.04 \mathrm{E}-02$ & $-2.82 \mathrm{E}-04$ & $3.24 \mathrm{E}-01$ & $0.16(0-0.32)$ \\
\hline
\end{tabular}


Table S2: Detailed results of the bivariate analysis of risk of death by SARS-CoV-2 when controlled for state, and median income

\begin{tabular}{|c|c|c|c|c|c|c|c|}
\hline Risk Factors & Estimate & $\begin{array}{l}\text { Standard } \\
\text { Error }\end{array}$ & Statistic & $p$-value & Conf.low & Conf.high & Estimate_95Cl \\
\hline Disability & $9.40 \mathrm{E}-02$ & 9.87E-02 & $9.51 \mathrm{E}-01$ & $3.43 E-01$ & $-1.01 \mathrm{E}-01$ & 2.88E-01 & $0.09(-0.10-0.29)$ \\
\hline Disability male & 1.37E-01 & $8.52 \mathrm{E}-02$ & $1.61 \mathrm{E}+00$ & $1.09 \mathrm{E}-01$ & $-3.11 \mathrm{E}-02$ & 3.06E-01 & $0.14(-0.03-0.31)$ \\
\hline Disability female & $1.43 \mathrm{E}-01$ & $9.00 \mathrm{E}-02$ & $1.59 \mathrm{E}+00$ & $1.14 \mathrm{E}-01$ & $-3.49 \mathrm{E}-02$ & $3.21 \mathrm{E}-01$ & $0.14(-0.04-0.32)$ \\
\hline Disability Black & $9.50 \mathrm{E}-02$ & $6.85 \mathrm{E}-02$ & $1.39 \mathrm{E}+00$ & $1.67 \mathrm{E}-01$ & $-4.04 \mathrm{E}-02$ & 2.31E-01 & $0.10(-0.04-0.23)$ \\
\hline Disability Asian & $-7.00 \mathrm{E}-02$ & 7.13E-02 & $-9.79 E-01$ & $3.30 \mathrm{E}-01$ & $-2.12 \mathrm{E}-01$ & 7.19E-02 & $-0.07(-0.21-0.07)$ \\
\hline Disability White alone & $1.89 \mathrm{E}-01$ & 8.98E-02 & $2.11 E+00$ & 3.67E-02 & $1.18 \mathrm{E}-02$ & 3.66E-01 & $0.19(0.012-0.37)$ \\
\hline Disability Hispanic & $-3.00 E-02$ & 7.92E-02 & $-3.83 \mathrm{E}-01$ & $7.02 \mathrm{E}-01$ & $-1.87 \mathrm{E}-01$ & $1.26 \mathrm{E}-01$ & $-0.03(-0.19-0.13)$ \\
\hline Disability 5 to 17 Years & $-5.10 \mathrm{E}-02$ & 7.63E-02 & $-6.67 \mathrm{E}-01$ & $5.05 \mathrm{E}-01$ & $-2.02 \mathrm{E}-01$ & 9.99E-02 & $-0.05(-0.20-0.1)$ \\
\hline Disability 18 to 34 Years & 1.66E-01 & 7.30E-02 & $2.27 \mathrm{E}+00$ & 2.43E-02 & 2.18E-02 & 3.10E-01 & $0.17(0.02-0.31)$ \\
\hline Disability 35 to 64 Years & $1.31 \mathrm{E}-01$ & $9.81 \mathrm{E}-02$ & $1.33 \mathrm{E}+00$ & $1.84 \mathrm{E}-01$ & $-6.28 \mathrm{E}-02$ & $3.25 \mathrm{E}-01$ & $0.13(-0.06-0.33)$ \\
\hline Disability 65 to 74 Years & $6.70 \mathrm{E}-02$ & $9.06 \mathrm{E}-02$ & 7.38E-01 & $4.62 \mathrm{E}-01$ & $-1.12 \mathrm{E}-01$ & 2.46E-01 & $0.07(-0.11-0.25)$ \\
\hline Disability 75 Years and Over & $-4.40 \mathrm{E}-02$ & 7.41E-02 & $-5.98 \mathrm{E}-01$ & $5.51 E-01$ & $-1.91 \mathrm{E}-01$ & $1.02 \mathrm{E}-01$ & $-0.04(-0.191-0.10)$ \\
\hline Disability hearing difficulty & $8.80 \mathrm{E}-02$ & 7.12E-02 & $1.23 E+00$ & $2.20 \mathrm{E}-01$ & $-5.30 \mathrm{E}-02$ & 2.28E-01 & $0.09(-0.05-0.23)$ \\
\hline Disability vision difficulty & $6.70 \mathrm{E}-02$ & $7.88 \mathrm{E}-02$ & 8.51E-01 & $3.96 \mathrm{E}-01$ & $-8.86 \mathrm{E}-02$ & 2.23E-01 & $0.07(-0.09-0.22)$ \\
\hline Disability cognitive difficulty & $9.00 \mathrm{E}-02$ & 8.79E-02 & $1.03 E+00$ & $3.06 \mathrm{E}-01$ & $-8.33 \mathrm{E}-02$ & 2.64E-01 & $0.09(-0.08-0.26)$ \\
\hline Disability ambulatory difficulty & 1.19E-01 & 9.00E-02 & $1.32 \mathrm{E}+00$ & $1.87 \mathrm{E}-01$ & $-5.85 \mathrm{E}-02$ & 2.97E-01 & $0.12(-0.06-0.30)$ \\
\hline Disability self-care difficulty & $6.10 \mathrm{E}-02$ & 7.48E-02 & 8.17E-01 & 4.15E-01 & $-8.67 \mathrm{E}-02$ & 2.09E-01 & $0.06(-0.09-0.21)$ \\
\hline $\begin{array}{l}\text { Disability independent living } \\
\text { difficulty }\end{array}$ & 1.49E-01 & 7.85E-02 & $1.89 \mathrm{E}+00$ & $6.02 \mathrm{E}-02$ & $-6.47 \mathrm{E}-03$ & 3.04E-01 & $0.15(-0.01-0.30)$ \\
\hline
\end{tabular}


medRxiv preprint doi: https://doi.org/10.1101/2020.06.24.20139212; this version posted June 26, 2020. The copyright holder for this preprint (which was not certified by peer review) is the author/funder, who has granted medRxiv a license to display the preprint in perpetuity.

It is made available under a CC-BY-ND 4.0 International license.

Table S1: Independent sample t-test with comprehensive summary statistics comparing counties data elements: mean, minimum, maximum, confidence interval lower and upper bound

\begin{tabular}{|c|c|c|c|c|c|}
\hline Data Elements & Mean+ & Minimum & Maximum & $\begin{array}{l}\text { 95\% Confidence } \\
\text { Interval Lower } \\
\text { Bound }\end{array}$ & $\begin{array}{l}\text { 95\% Confidence } \\
\text { Interval Upper } \\
\text { Bound }\end{array}$ \\
\hline Total population & 276905.5 & 1129.0 & 10039107.0 & 206987.7 & 346823.2 \\
\hline $\begin{array}{c}\text { SARS-CoV-2 infection } \\
\text { rate }^{*}\end{array}$ & 1593.0 & 15.4 & 20458.0 & 1302.8 & 1883.3 \\
\hline $\begin{array}{l}\text { SARS-CoV-2 related } \\
\text { death rate }\end{array}$ & 3.8 & 0.3 & 10.1 & 3.5 & 4.1 \\
\hline Retail mobility & -0.5 & -1.0 & 0.4 & -0.5 & -0.4 \\
\hline Grocery mobility & -0.2 & -0.7 & 0.3 & -0.2 & -0.1 \\
\hline Park mobility & 0.0 & -0.9 & 1.8 & 0.0 & 0.1 \\
\hline Transit mobility & -0.5 & -0.9 & 0.7 & -0.5 & -0.4 \\
\hline Work mobility & -0.4 & -0.7 & 0.5 & -0.4 & -0.4 \\
\hline Resident mobility & 0.1 & 0.0 & 0.3 & 0.1 & 0.1 \\
\hline Black male & 5.3 & 0.0 & 37.5 & 4.6 & 6.0 \\
\hline Black female & 4.9 & 0.1 & 32.8 & 4.2 & 5.6 \\
\hline Asian male & 1.5 & 0.0 & 19.0 & 1.2 & 1.7 \\
\hline Asian female & 1.6 & 0.0 & 19.3 & 1.4 & 1.9 \\
\hline White male & 37.1 & 4.5 & 50.3 & 36.1 & 38.1 \\
\hline White female & 37.6 & 4.7 & 49.0 & 36.5 & 38.6 \\
\hline Hispanic male & 5.2 & 0.4 & 42.3 & 72.6 & 76.7 \\
\hline Hispanic female & 4.8 & 0.4 & 42.3 & 4.1 & 5.5 \\
\hline Median income & 69910.1 & 30717.0 & 147878.0 & 67934.9 & 71885.4 \\
\hline Poverty & 15.1 & 4.6 & 48.6 & 14.5 & 15.7 \\
\hline High school & 87.6 & 68.5 & 96.1 & 87.0 & 88.1 \\
\hline Bachelors & 24.6 & 7.4 & 60.8 & 23.5 & 25.7 \\
\hline Insured male & 91.5 & 72.4 & 97.5 & 91.1 & 91.8 \\
\hline Insured female & 93.6 & 80.1 & 98.4 & 93.3 & 93.9 \\
\hline Insured Black & 91.4 & 46.7 & 100.0 & 90.7 & 92.0 \\
\hline Insured Asian & 90.3 & 0.0 & 100.0 & 89.0 & 91.5 \\
\hline Insured Hispanic & 85.9 & 30.3 & 100.0 & 84.9 & 87.0 \\
\hline Insured White alone & 93.9 & 80.9 & 98.4 & 93.6 & 94.1 \\
\hline Medicaid & 23.2 & 6.9 & 48.4 & 22.5 & 23.9 \\
\hline Disability & 15.0 & 6.5 & 28.5 & 14.6 & 15.4 \\
\hline Disability male & 13.1 & 7.1 & 22.3 & 12.6 & 13.5 \\
\hline Disability female & 13.4 & 7.7 & 20.5 & 13.0 & 13.8 \\
\hline Disability Black & 15.4 & 4.5 & 57.7 & 14.4 & 16.4 \\
\hline Disability Asian & 7.9 & 2.3 & 33.1 & 7.1 & 8.6 \\
\hline Disability White & 14.0 & 7.2 & 20.7 & 13.6 & 14.4 \\
\hline Disability Hispanic & 11.4 & 3.6 & 33.0 & 10.6 & 12.2 \\
\hline Disability 5 to 17 years & 6.3 & 1.9 & 13.9 & 6.0 & 6.7 \\
\hline Disability 18 to 34 years & 7.1 & 2.3 & 16.4 & 6.8 & 7.4 \\
\hline Disability 35 to 64 years & 13.0 & 4.9 & 25.6 & 12.5 & 13.6 \\
\hline Disability 65 to 74 years & 23.3 & 10.0 & 36.1 & 22.6 & 24.1 \\
\hline $\begin{array}{c}\text { Disability } 75 \text { years and } \\
\text { over }\end{array}$ & 47.1 & 32.3 & 67.7 & 46.2 & 47.9 \\
\hline
\end{tabular}


medRxiv preprint doi: https://doi.org/10.1101/2020.06.24.20139212; this version posted June 26, 2020. The copyright holder for this preprint (which was not certified by peer review) is the author/funder, who has granted medRxiv a license to display the preprint in perpetuity. It is made available under a CC-BY-ND 4.0 International license.

\begin{tabular}{|c|c|c|c|c|c|}
\hline $\begin{array}{c}\text { Disability hearing } \\
\text { difficulty }\end{array}$ & 3.7 & 1.7 & 7.2 & 3.5 & 3.8 \\
\hline $\begin{array}{c}\text { Disability vision } \\
\text { difficulty }\end{array}$ & 2.2 & 0.8 & 4.8 & 2.1 & 2.4 \\
\hline $\begin{array}{c}\text { Disability cognitive } \\
\text { difficulty }\end{array}$ & 5.4 & 2.6 & 10.5 & 5.2 & 7.6 \\
\hline $\begin{array}{c}\text { Disability ambulatory } \\
\text { difficulty }\end{array}$ & 7.0 & 3.4 & 11.2 & 6.7 & 2.8 \\
\hline $\begin{array}{c}\text { Disability self-care } \\
\text { Difficulty }\end{array}$ & 2.7 & 1.1 & 6.1 & 2.6 & 6.3 \\
\hline $\begin{array}{c}\text { Disability independent } \\
\text { living difficulty }\end{array}$ & 6.1 & 2.9 & 10.7 & 5.9 & \\
\hline
\end{tabular}

+ All reported numbers are in percent except total population, SARS-CoV-2 infection rate, and median income.

* Rate of SARS-CoV-2 infection in one per Million 
medRxiv preprint doi: https://doi.org/10.1101/2020.06.24.20139212; this version posted June 26, 2020. The copyright holder for this preprint (which was not certified by peer review) is the author/funder, who has granted medRxiv a license to display the preprint in perpetuity. It is made available under a CC-BY-ND 4.0 International license.

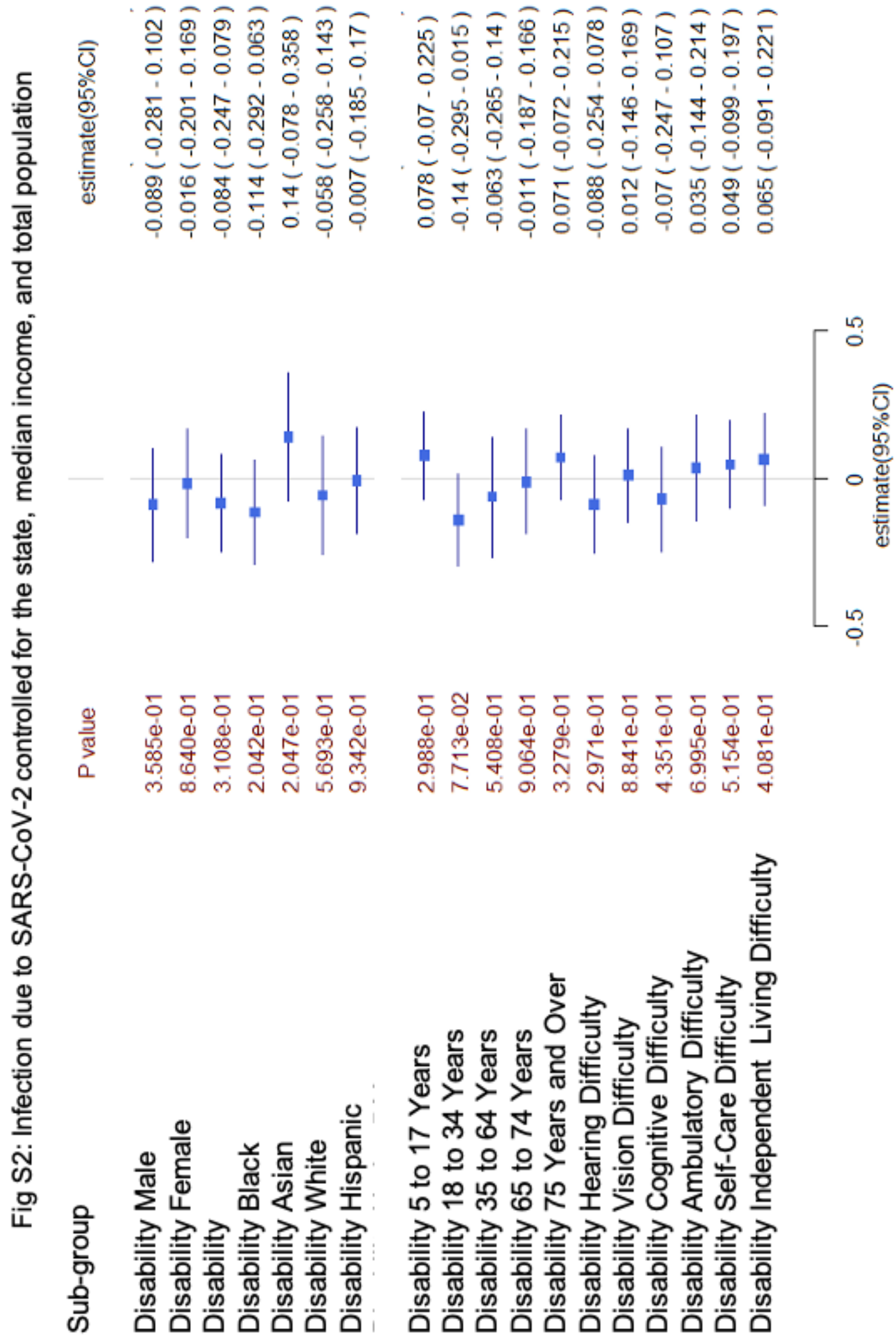


medRxiv preprint doi: https://doi.org/10.1101/2020.06.24.20139212; this version posted June 26, 2020. The copyright holder for this preprint (which was not certified by peer review) is the author/funder, who has granted medRxiv a license to display the preprint in perpetuity. It is made available under a CC-BY-ND 4.0 International license.

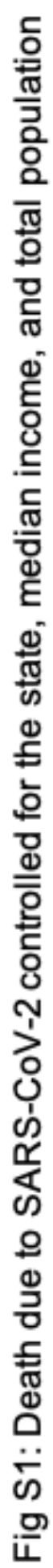
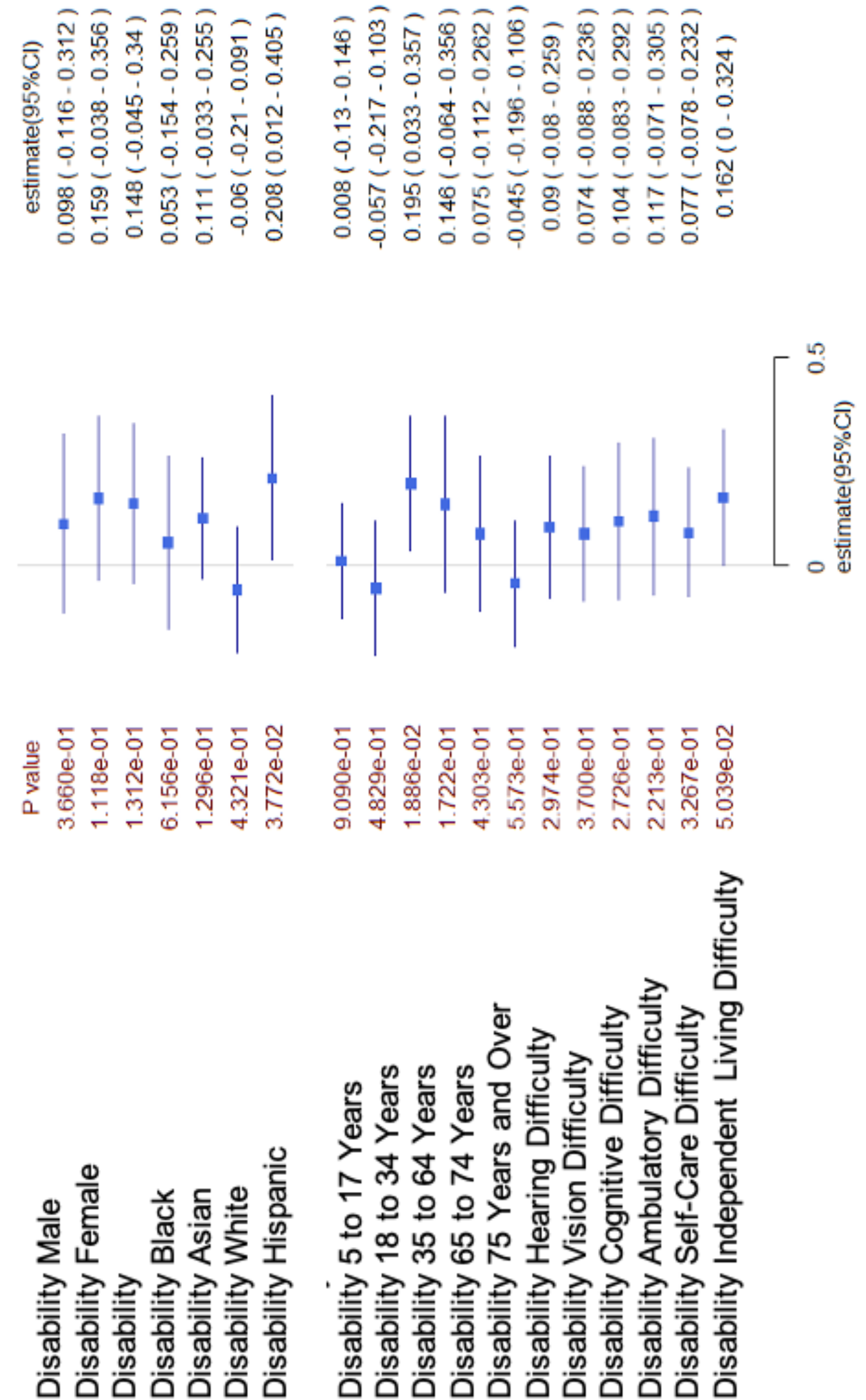


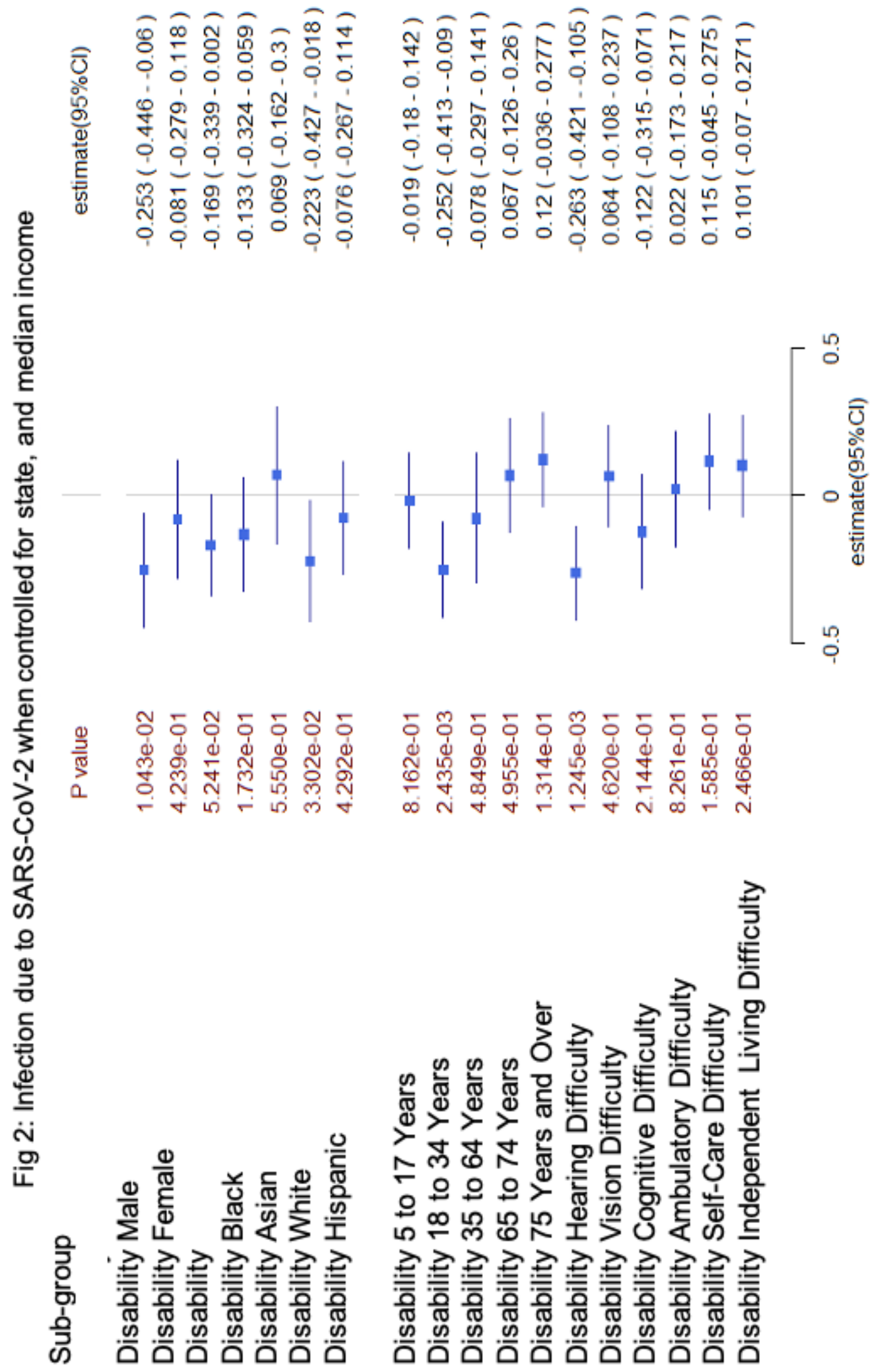


Fig 1: Death due to SARS-CoV-2 when controlled for state and median income

Sub-group

Disability Male

Disability Female

Disability

Disability Black

Disability Asian

Disability White

Disability Hispanic

Disability 5 to 17 Years

Disability 18 to 34 Years

Disability 35 to 64 Years

Disability 65 to 74 Years

Disability 75 Years and Over

Disability Hearing Difficulty

Disability Vision Difficulty

Disability Cognitive Difficulty

Disability Ambulatory Difficulty

Disability Self-Care Difficulty

Disability Independent Living Difficulty
$P$ value

\section{$1.093 \mathrm{e}-01$ \\ $1.144 \mathrm{e}-01$ \\ 3. $426 \mathrm{e}-01$ \\ $1.671 \mathrm{e}-01$ \\ 3.302e-01 \\ 3.672e-02 \\ 7.022e-01}

5.054e-01

$2.434 \mathrm{e}-02$

$1.838 \mathrm{e}-01$

4.615e-01

$5.510 \mathrm{e}-01$

2.201e-01

3.960e-01

3.056e-01

1.871e-01

4.153e-01

$6.023 e-02$ estimate $(95 \% \mathrm{Cl})$

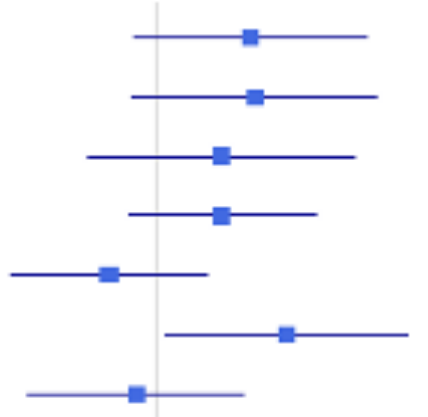

$0.137(-0.031-0.306)$

$0.143(-0.035-0.321)$

$0.094(-0.101-0.288)$

$0.095(-0.04-0.231)$

$-0.07(-0.212-0.072)$

$0.189(0.012-0.366)$

$-0.03(-0.187-0.126)$

$-0.051(-0.202-0.1)$

$0.166(0.022-0.31)$

$0.131(-0.063-0.325)$

$0.067(-0.112-0.246)$

$-0.044(-0.191-0.102)$

$0.088(-0.053-0.228)$

$0.067(-0.089-0.223)$

$0.09(-0.083-0.264)$

$0.119(-0.059-0.297)$

$0.061(-0.087-0.209)$

$0.149(-0.006-0.304)$ 